23. Давыдова А.В. Иволгинский археологический комплекс. Т. 1: Иволгинское городище // Археологические памятники сюнну. СПб.: Фонд «АзиатИКА», 1995. Вып. 1.97 с.

24. Давыдова А.В. Иволгинский археологический комплекс. Т. 2: Иволгинский могильник // Археологические памятники сюнну. СПб.: Петербургское Востоковедение, 1996. Вып. 2. 176 с.

25. Миняев С.С. Дырестуйский могильник // Археологические памятники сюнну. СПб.: Филфак СПбГУ, 2007. Вып. 3. 233 с.
26. Скрипкин А.С. О восточных связях сарматов во II-I вв. до н.э. // Сарматы и внешний мир: мат-лы VIII всерос. (с междунар. участием) науч. конф. «Проблемы сарматской археологии и истории». Уфа: Институт истории, языка и литературы; Уфимский науч. центр РАН; центр «Наследие», 2014. С. 216-222.

Статья подготовлена в рамках грантового финансирования Комитета науки Министерства образования и науки Республики Казахстан, ИРН проекта АР05131573.

\title{
THE BELT BUCKLES OF THE EARLY SARMATIAN PERIOD OF TURGAY
}

(C) 2020

Seitov Abay Meiramovich, researcher of Prehistoric Department; researcher of Archaeological Laboratory

A.Kh. Margulan Institute of Archaeology (Almaty, Republic of Kazakhstan);

Kostanay State University A. Baitursynov (Kostanay, Republic of Kazakhstan)

Abstract. The paper is devoted to belt buckles of the early Sarmatian period of the Turgay steppes. Turgay deflection is a vast territory located in the north-western part of Kazakhstan. In the north, Turgay deflection turns into the west Siberian lowland, and in the south it turns into the Turan lowland. In the west, the bend touches the Trans-Ural plateau, while in the east - the Kazakh hills. Three buckles originating from burial № 5A of mound 1 of the Karatomar burial ground and mound 1 of the Kenysh 3 mound group are analyzed. The paper deals with the cultural and chronological position of Turgay belt buckles in the context of the distribution of such products of the belt headset on the territory of Eurasia. The problem of the origin and chronology of these items is also touched upon. Buckles similar to the Karatomar one have so far been found only on the territory from Central Asia and Kazakhstan to the Lower Volga region. Kenysh buckle finds an analogy from the Volga-Don interfluves to the north of China. In General, types of buckles, similar to Turgay, existed in the II-I centuries BC. The studied buckles should be considered in the context of the general fashion for wearing a belt headset made of metal, bone and stone, associated with the military activity of the Huns.

Keywords: Steppes of Eurasia; North-Western Kazakhstan; Turgay; Turgay deflection; Karatomar burial ground; Kenysh 3 barrow group; early Sarmatian time; early Sarmatian culture; Sarmatians; Huns; belt buckles; II-I centuries $\mathrm{BC}$; panther; camel; jet; clay shale.

$* * *$

УДК 902.26

DOI 10.24411/2309-4370-2020-11204

Статья поступила в редакцию 28.01.2020

\section{КУРГАНЫ САМАРСКОЙ ОБЛАСТИ В ФОКУСЕ СПУТНИКОВЫХ СНИМКОВ}

(C) 2020

\author{
Вальков Денис Владимирович, начальник отдела археологических исследований \\ Научно-производственный цеентр «Универсальные технологии и разработки» \\ (2. Самара, Российская Федерация)
}

Аннотация. Статья сфокусирована на двух археологических проблемах: корректность системы учета па-
мятников археологии и эффективность их обнаружения, особенно в зонах предстоящих строительных работ.
Актуальность проблем раскрыта автором на примере истории исследования курганного могильника «Самар-
ский (Просвет) І» и на примере обследования его территории методом анализа разнородных данных дистан-
ционного зондирования Земли (ДЗ3). Установлено, что за период 1973-2016 гг. памятник обследовали не
менее 8 экспедиций. За это же время накопившиеся ошибки в описании привели к тому, что в системе учета
объектов археологического наследия Самарской области этот памятник под одним названием зафиксирован
под двумя номерами и в двух административных районах. На территории памятника автор сформировал
набор данных ДзЗ, включающий архивные и современные космические снимки. Затем все эти данные и ме-
стоположения курганов, выявленных предшествующими исследователями, в специализированном про-
граммном продукте приведены к единой проекции. По разным данным д33, выделяется от 31 до 180 зон ха-
рактерной контрастной пикселизации. Местоположения всех курганов, ранее выявленных в поле, совпадают
с ними. Следовательно, многие из этих зон также могут быть полностью распаханными курганами, сохран-
ности которых угрожает строительство нефтепроводов по соседству. По этой методике произведена провер-
ка территории еще четырех курганных могильников, обследованных в 2015-2017 гг. и расположенных в зо-
нах строительства. На них обнаружены курганы, не выявленные исследователями ранее и, соответственно, по-
врежденные в ходе строительных работ. Выводы: полевому археологическому обследованию должен предше-
ствовать анализ разнородных данных ДЗ3; наиболее надежным методом является исследование курганных мо-
гильников раскопом сплошной площадью, накрывающим и межкурганное пространство. Однако этот же ме-
тод, как наиболее затратный, требует корректировки по данным ДзЗ и иными, не инвазивными методами. 
Ключевые слова: Самарская область; курганный могильник «Самарский (Просвет) І»; курганный могильник «Николаевка I»; курганный могильник «Михайловский II»; курганный могильник «Конезавод II»; анализ данных дистанционного зондирования Земли (ДЗ3); ГИС; космические снимки; учет объектов археологического наследия; разрушение памятников археологии.

Работы экспедиций Общества археологии, истории, этнографии и естествознания под руководством Гольмстен Веры Владимировны в период 19201930 гг. являются первым системным археологическим обследованием региона [1, с. 99-112]. Однако значительная часть из 1200 памятников археологии, открытых экспедициями Общества, к настоящему времени остаются неизвестными современным исследователям и не поставлены на государственный учёт и охрану. Многолетние работы автора по поиску, верификации и введению в современный научный оборот ранее открытых памятников археологии, информация о которых была утрачена, периодически дают положительный эффект. Последний удачный пример связан с верификацией т.н. «курганника у с. Домашка», исследованном экспедицией Общества в 1924 г. [2, с. 99-112]. Несмотря на неоднократное упоминание в литературе, точное местоположение этого памятника археологии не установлено, следовательно, он до настоящего времени не является официально открытым. Медный котёл, происходивший из раскопок этого «курганника», является одним из редчайших образцов металлопластики финала эпохи ПБВ [3, с. 105-107] и в этом статусе просто требовал точного определения своего места находки. Автор полагает, что ему удалось локализовать местоположение этого курганного могильника - методом анализа данных ДЗЗ (здесь и далее - дистанционного зондирования Земли), подтверждённого верификацией на местности [4].

При проведении анализа данных Д33 в обширной округе современного с. Домашка, автор случайно обратил внимание на хорошо известный курганный могильник «Просвет I», расположенный на границе Волжского и Кинельского районов Самарской области (рис. 1: 1). Данный памятник археологии был открыт в 1973 г. И.Р. Тихомоловой, назван ею «Самарский курганный могильник» и с того времени неоднократного обследовался различными археологическими экспедициями и методами. Многочисленность исследователей, а также расположение кургана на границе двух административных районов, предопределило заметные разночтения в описании этого памятника. Он находится в непосредственной близости от обширного комплекса смешения и перекачки нефти ЛПДС «Самара», перманентное развитие которого, в том числе и в сторону известных курганов, внушает беспокойство за их сохранность.

Анализ данных Д3З на территории указанного объекта археологического наследия и его ближайших окрестностей привел автора к серьёзному противоречию с устоявшимся мнением об этом памятнике. Полученное количество и местоположение т.н. «зон контрастной пикселизации» многократно превосходило число всех ранее выявленных исследователями курганов. Для проверки правильности интерпретации этих «зон» как курганов автор провёл анализ ещё нескольких курганных могильников, находящихся в зонах хозяйственного освоения и обследованных методами охранно-спасательных раскопок в 2015-2018 гг. (рис. 1).
Полученные выводы неумолимо выводят нас на две традиционные проблемы, заходящие далеко за рамки чисто академического круга вопросов:

- корректный учет объектов археологического наследия;

- эффективность поиска археологических объектов, не обнаруживаемых традиционными полевыми методами, при обследовании зон хозяйственного освоения.

Для понимания всей цепочки доказательств автор посчитал необходимым напомнить краткие вехи истории исследования данного иллюстративного памятника археологии.

В первоначально открытом в 1973 г. «Самарском курганном могильнике» было зафиксировано 7 курганов, разделённых на две группы (рис. 2).

Следующий план памятника был составлен в 1975 г. В.В. Камаевым, который, помимо двух вышеуказанных групп, указал ещё 3 кургана, расположенных примерно в 1,1 км к ЮВ [5, с. 3]. Это очень важный для дальнейшего понимания ситуации план, ибо 3 данных кургана больше нигде не отмечены (рис. 3: 1). Необходимо отметить, что курганы №№ 1-8 этого плана административно расположены в границах Волжского района, а курганы №№ 9-11 - уже в Кинельском районе. К сожалению, и этот исследователь не отметил знак ПГГС (тригопункт), установленный на каком-то из курганов с номерами 5-8, что затрудняет точную привязку планов 1973 и 1975 годов.

В 1991 г. А.Ф. Кочкина обследовала две группы курганов, соответствующих плану 1973 года, и впервые изменила их нумерацию. В условно «северную группу» были внесены курганы №№ 1-3 (произвольно соответствуют курганам №№ 5-8 по планам 1973 и 1975 годов, один из курганов не найден). В условно «центральную группу» - курганы №№ 4-6 (произвольно соответствуют курганам №№ 1-4 по планам 1973 и 1975 годов). Кроме того, исследовательница отметила, что один курган разрушен при строительстве автодороги в с. Домашкины Вершины, а курган № 6 - траншеей при строительстве нефтепровода [6, с. 59].

В 1996 г. две команды исследователей, независимо друг от друга, обследовали эту территорию. В результате появились два плана и начались существенные расхождения в наименовании и описании памятника. На плане, подготовленном сотрудниками археологической лаборатории Самарского педуниверситета, памятник назван «Просвет I», на нём отмечено 5 курганов, расположенных в границах Волжского района, в «северной группе» осталось всего два кургана. В дальнейшем этот план лёг в основу плана 2005 г. (см. рис. 4).

В это же время А.Ф. Кочкина провела обследование этого же водораздельного плато и в 1,5 км к ЮВ выявила группу из 6 курганов. Они обоснованно были выделены в отдельный объект археологического наследия - курганный могильник «Парфеновка», находящийся целиком в границах Кинельского района (рис. 3: 2).

Необходимо отметить, что все курганы, описанные А.Ф. Кочкиной в 1996 г, не имеют отношения к 
Вальков Д.В.

Курганы Самарской области в фокусе спутниковых снимков

Исторические науки и археология

ранее открытым, поскольку расположены приблизительно в 300-500 м к ЮВ от курганов №№ 9-11, отмеченных на плане 1975 г. Обоснование этого вывода будет приведено в разделе методика.

Следующий этап исследования памятника относится к 2005 г, когда объединённая экспедиция нескольких самарских научных организаций раскопала группу курганов №№ 3, 4, 5, 7, 8, 9 из состава курганного могильника «Просвет I», согласно плану СГПУ 1996 г. [7, с. 248, 274]. К началу этих охранноспасательных работ в рельефе остались видны только курганы № 3, № 4 и № 5. Между ними на пашне наблюдались только более светлые пятна совершенно распаханных насыпей. По этой причине вся территория этой курганной группы была обследована сплошным раскопом, захватившим и межкурганное пространство. На местах светлых пятен были обнаружены курганы №№ 7-9. Для целей настоящего исследования применение такой методики оказалось особенно важным.
В 2012 г. территория к югу от комплекса ЛПДС «Самара», в границах Кинельского района, была обследована С.А. Кондратьевым, который подробнейшим образом восстановил историографию по памятнику и обследовал группу курганов, выявленных А.Ф. Кочкиной в 1996 году [8, с. 15-18]. Исследователь актуализировал план 1996 г, обнаружил новые курганы, но внёс их в состав курганного могильника «Самарский (Просвет) I». Своё мнение он обосновал возможным существованием многочисленных, но полностью распаханных курганов, протянувшихся цепочкой с ЮВ на С3 между обеими группами этого курганного поля. В работе над настоящей статьей были использованы только координаты курганов в системе WGS-84, определённые этим исследователем, поскольку Отраслевой архив ИА РАН не разрешает копирование планов за истекшие 10 лет со времени поступления отчётов (соотношение местоположения курганов по А.Ф. Кочкиной и С.А. Кондратьеву см. рис. 4).

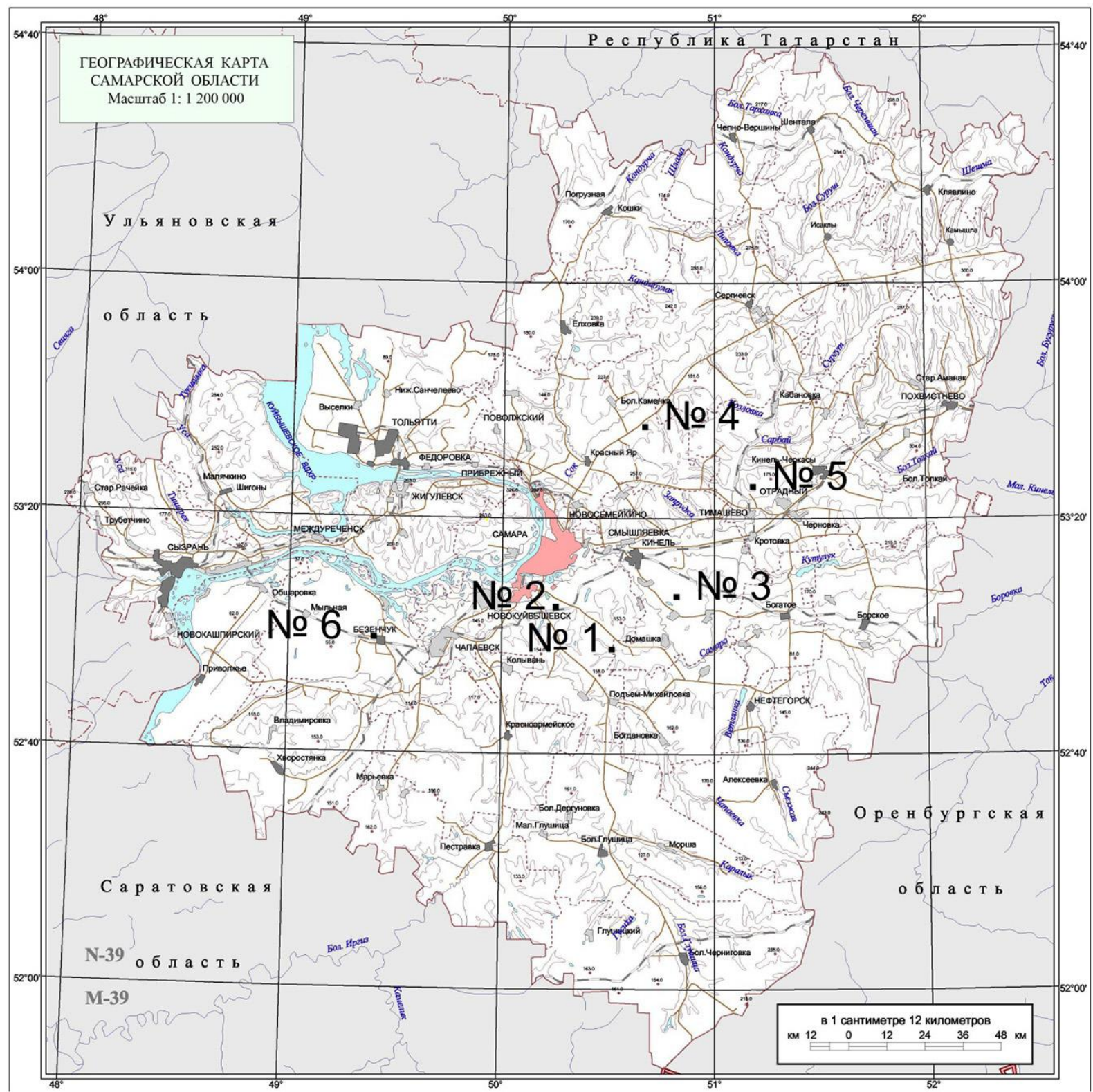

Рисунок 1 - Расположение памятников археологии на административной карте Самарской области:

№ 1 - курганный могильник «Самарский (Просвет) І»; № 2- курганный могильник «Николаевка І»;

№ 3- курганный могильник «Михайловский II»; № 4- курганный могильник «Конезавод II»;

№ 5- курганный могильник «Садгород IV»; № 6- курганные могильники «Безенчук I» - «Безенчук IV» 


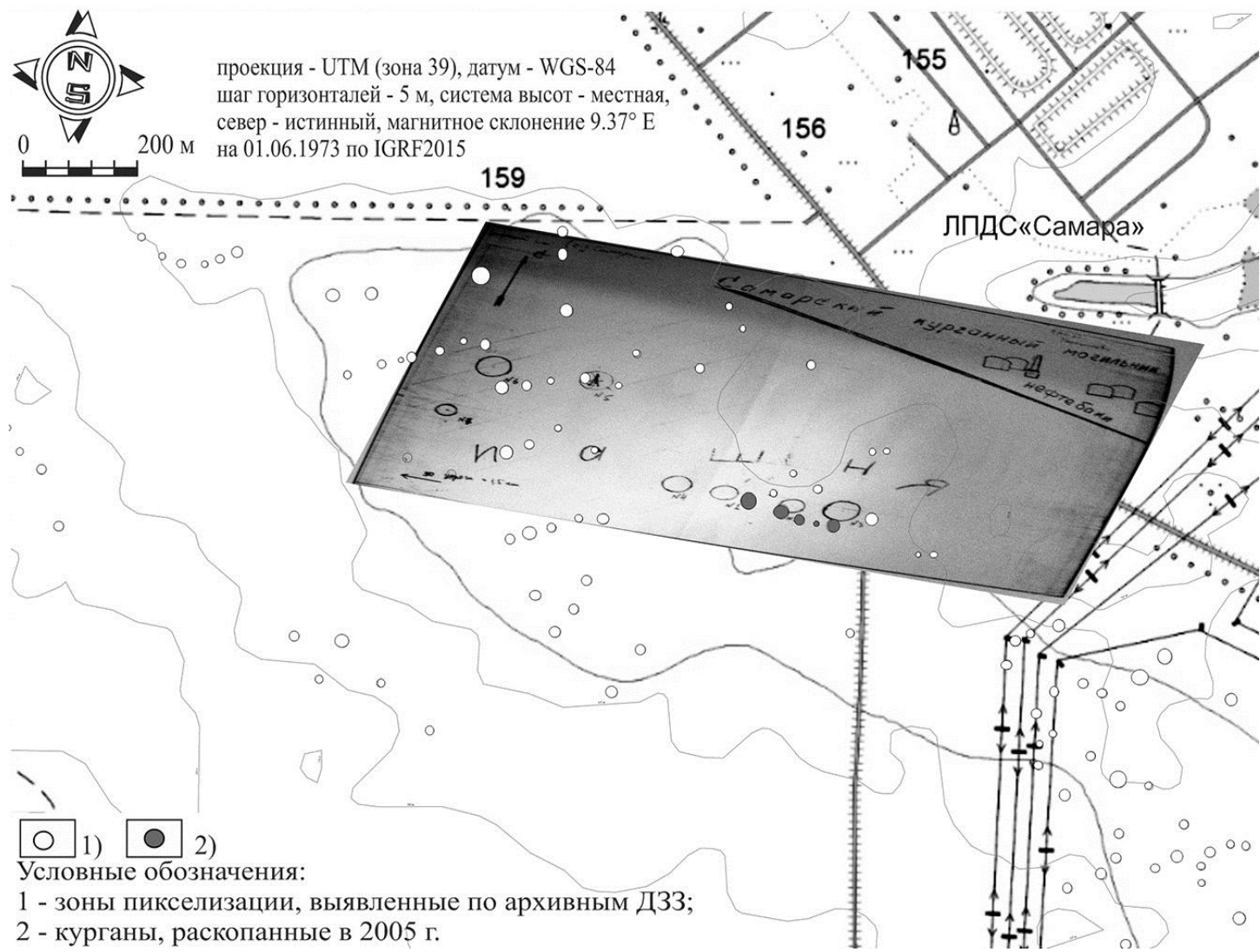

Рисунок 2 - Архивный план КМ «Самарский» по И.Р. Тихомоловой, 1973 г.

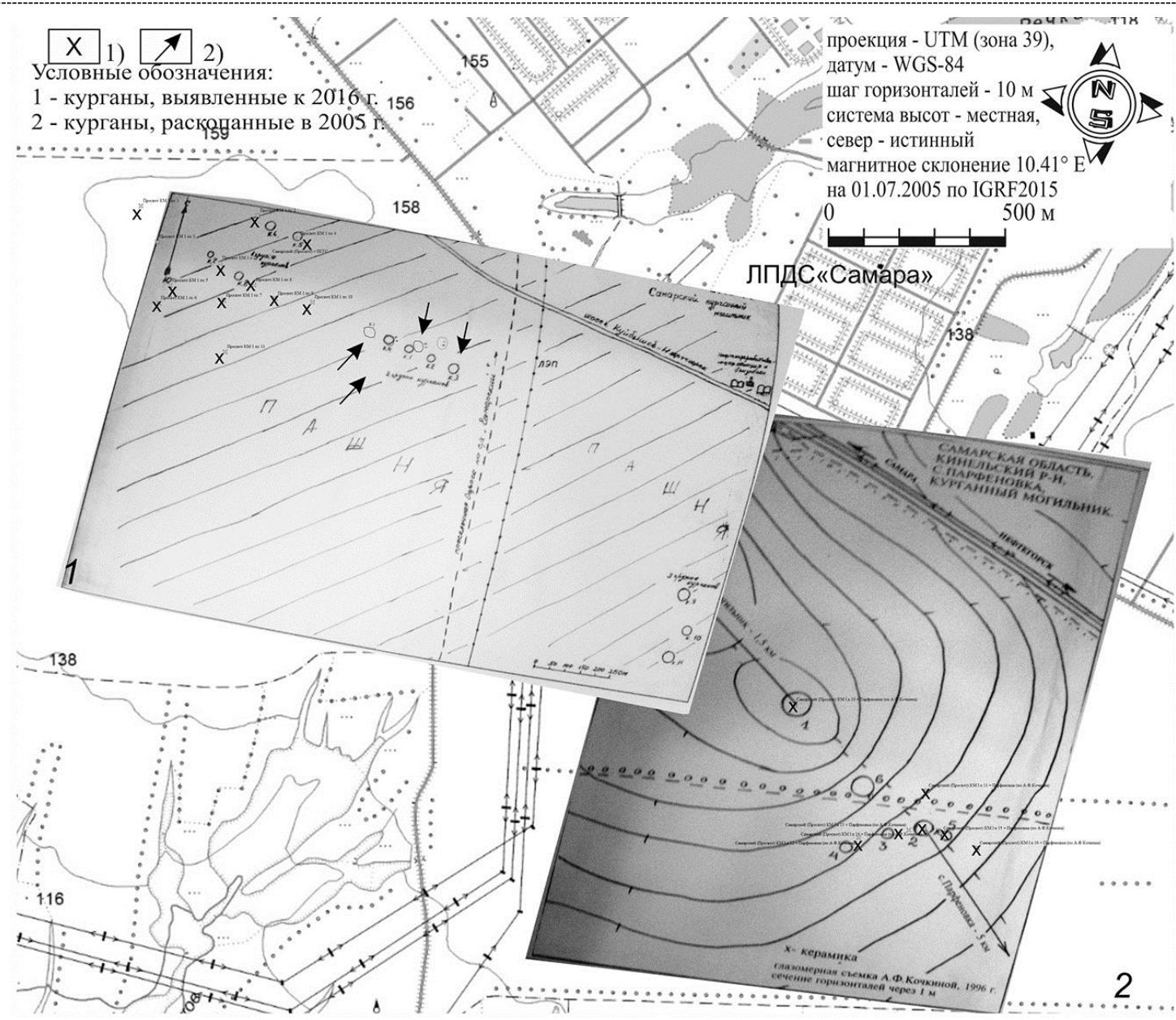

Рисунок 3 - Архивные планы курганного могильника:

1 - «Самарский (Просвет) I» (1975 г.); 2 - «Парфеновка» (1996 г.) 
Следующим эту территорию обследовал И.И. Дрёмов в 2016 году, который определил координаты в системе WGS-84 для курганов № 1 и № 2, согласно плану курганного могильника «Просвет I» 2005 года. Кроме того, исследователь выявил на космоснимке не менее 12 почвенных структур и верифицировал их в поле как полностью распаханные насыпи курганов [9, с. 116-117]. Координаты этих курганов и почвенных структур также были использованы в работе над настоящей статьей (соотношение местоположения курганов, выявленных И.И. Дрёмовым и иными исследователями, см. рис. 3 ; рис. 4 ; рис. 6).

Поскольку Отраслевой архив ИА РАН не выдаёт для ознакомления отчёты за истекшие три года со времени поступления, автору неизвестны исследования, проведённые на этой территории после 2016 г.

В итоге на этой территории было зафиксировано следующее число курганов: по плану 1973 г. их выявлено 7, по плану 1975 г. - 11, по двум планам 1996 г. - 5 и 6, по плану 2005 г. - 9, по исследованию С.А. Кондратьева - 19 (включая ранее раскопанные), по исследованию И.И. Дрёмова - 14. Из 12 курганов, выявленных И.И. Дрёмовым по неназванному космоснимку, с планами 1973 г. и 1975 г. соотносятся только 3 кургана. Судьба курганов из этого общего перечня такова: раскопано - 7 , утрачено или не найдено - 3 , достоверно локализовано на местности и стоят на учете -9 .

Кроме историографической стороны вопроса, существует и официально-учетная. Формально курганный могильник «Самарский (Просвет)» задокументирован в «Перечне выявленных объектов археологического наследия Самарской области» по Волжскому району под № 77, как находящийся в 2,4 км к юго-востоку от пос. Просвет. В этом же «Перечне», под № 66 по Кинельскому району фигурирует курганный могильник «Самарский (Просвет) к.№ 1016», определённый в 2012 году С.А. Кондратьевым и позиционируемый им в 2,5 км к северо-востоку от с. Домашкины Вершины [10]. Никаких иных объектов археологического наследия на этом участке местности, по официальным данным, нет.

Поскольку данный «Перечень» администрируется государственным органом, уполномоченным в сфере охраны ОКН Самарской области, то именно на его основании ведётся учёт и обеспечивается сохранность памятников археологии региона. Таким образом, с одной стороны, формально не существует курганного могильника «Просвет I» и раскопанных в 2005 г. курганов из его состава, а курганный могильник «Парфеновка I» соотнесён совсем с другим памятником, нежели предложенный А.Ф. Кочкиной. С другой стороны - разнесённые почти на 1,5 км друг от друга группы курганов, расположенные в разных административных районах, оказались приписанными к одному ОАН. Получается, что этот памятник теперь проходит в «Перечне» под двумя номерами. В целом обоснованное предположение С.А. Кондратьева - о наличии между известных групп множества распаханных насыпей, в данном случае лишь внесло неоправданную путаницу в систему учёта ОАН.

Подробный обзор истории исследования этого памятника призван проиллюстрировать истоки и сложность проблемы администрирования археологической деятельности, стоящую перед госорганом: каким об- разом, невзирая на все усилия сторон, в систему учёта ОАН региона продолжает поступать и накапливаться искажённая или нерелевантная информация.

Использование данных ДЗ3 и геопространственный анализ отчасти помогают как распутыванию подобных историографических коллизий, так и поиску археологических объектов в зонах активной хозяйственной деятельности. Для рассматриваемой территории анализ космоснимков удачно применил И.И. Дрёмов (см. выше). Однако для изучения сложных памятников или территорий явно недостаточно просто «перелистать» разновременные снимки в Google Earth или разнородные - в SASPlanet. Применяемая автором методика не является особенно оригинальной, скорее это пример последовательного системного масштабирования усилий.

\section{Методика исследования}

Для соотнесения результатов работ предшествующих исследователей между собой была произведена привязка всех доступных архивных планов к современной геоподоснове по характерным точкам. Эта процедура является также вспомогательно-исследовательской - в плане критики источников. Как известно, программные алгоритмы, реализующие геопривязку изображения по характерным точкам, очень чувствительны к нарушениям геометрических пропорций этого изображения. Если относительные расстояния между объектов, изображённых на исследуемом архивном плане, были изначально переданы неправильно, то при попытке «растянуть» его на современную геоподоснову программа свернёт такой план в подобие ленты Мёбиуса. Такой же эффект или существенные нарушения пропорций архивного плана будут наблюдаться при неправильном выборе характерных точек либо при неудачном поиске им соответствий. Поэтому при выборе характерных точек приоритет отдавался надёжно верифицированным курганам.

После продолжительного подбора характерных точек инструментально вычерченные планы пережили процедуру ортотрансформирования с допустимыми искажениями (рис. 2 ; рис. 3 ; рис. 4). Для архивных планов использована процедура устранение девиации магнитного компаса с использованием принятых моделей компенсации дрейфа магнитного поля Земли (использована модель International Geomagnetic Reference Field). Дата расчета склонения стрелки компаса приведена на соответствующих планах ориентировочно, но, учитывая их общую лаконичность, погрешностью в пределах 1 градуса можно пренебречь. Наибольшие трудности ожидаемо возникли с глазомерным планом 1973 г. - не удалось соотнести курганы № 6 и № 7 с ныне известными, а группа курганов №№ 1-4 очень сильно растянулась в пространстве (здесь приведена нумерация этих курганов, согласно И.Р. Тихомоловой; у других исследователей она иная). Так же с большой долей условности был нами привязан и глазомерный план 1975 года. Выделенная на нём юго-восточная группа курганов №№ 9-11 не может быть соотнесена с ныне известными - при попытке связать их с курганами, выявленными А.Ф. Кочкиной и точно закоординированными С.А. Кондратьевым, план неоправданно растягивается по оси СЗ-ЮВ.

Ортотрансформированные архивные планы, план раскопа 2005 г, планы всех курганов, все доступные 
автору данные Д33, а также определённые различными исследователями координаты курганов были приведены к единой проекции (UTM, зона 39). Далее был проведён анализ всего доступного автору набора данных Д3З, включающего около 15 космических снимков оптического диапазона. Для уточнения рельефа использовалась цифровая модель местности, базирующаяся на данных SRTM-3 (радарная съёмка поверхности Земли, выполненная в 2000 г. с борта космического корабля Space Shuttle «Endeavor», миссия STS-99). Космические снимки были представлены архивными и современными панхроматическими и мультиспектральными изображениями, полученными как из открытых источников сети интернет, так и приобретёнными у вендоров отрасли. Для достижения максимальной точности сведения все снимки были перепривязаны по характерным точкам и ортотрансформированы. Орбитальная привязка кадров - игнорирована, проекции и привязки снимков, полученных из открытых геосервисов, не использовались.

В результате на архивном космическом снимке на месте раскопанных в 2005 г. курганов и по всей округе были обнаружены многочисленные зоны характерной контрастной пикселизации (рис. 5).

После инверсирования на этом снимке оказались хорошо различимы пятна насыпей курганов № 3, № 4 и № 5, практически попиксельно совпадающие с их контурами, зафиксированными некогда в поле [5, c. 275]. При этом зоны характерной контрастной пикселизации, соответствующие несомненным курганам №№ 7-9, остались очень слабо различимы (рис. 6).

Далее был применён метод своеобразного «обратного инжиниринга» - архивный космический снимок был подвергнут обработке различными фильтрами, чтобы выявить характеристики, при которых курганы №№ 7-9 стали различимы. Затем полученные условия фильтрации были приложены ко всему космическому снимку, покрывающему участок местности на рис. 7. Результат получился немного не тот, на который рассчитывал автор. На выходе, для этой территории, получилось весьма внушительное число зон контрастной пикселизации (не менее $180-$ !), которые по характеристикам отбора могли быть интерпретированы как курганы.

Поскольку автор не располагает данными о столь огромных курганных полях в Среднем Поволжье, полученные значения были подвергнуты проверке по другим данным Д33. На всех космических снимках, покрывающих обследуемую территорию, выделялись зоны контрастной пикселизации. Все работы по выделению таких зон проводились в условиях «слепого теста» - благодаря оверлейной организации набора данных каждый снимок анализировался по отдельности, и только в финале производилось сведение данных и сопоставление их с архивными планами.

Для упрощения обработки все данные Д3З были сгруппированы в три условных блока: архивные панхроматические, современные панхроматические и современные мультиспектральные. При их раздельном анализе количество зон характерной контрастной пикселизации оказалось намного меньше: 53 зоны выявлено на всех современных панхроматических и 83 зоны - на всех современных мультиспектральных.

Все выявленные по всем данным Д3З зоны контрастной пикселизации отражены на объединённом плане (рис. 7). Отдельными значками на плане отмечены зоны, выявленные на каждом из трёх условных блоков.

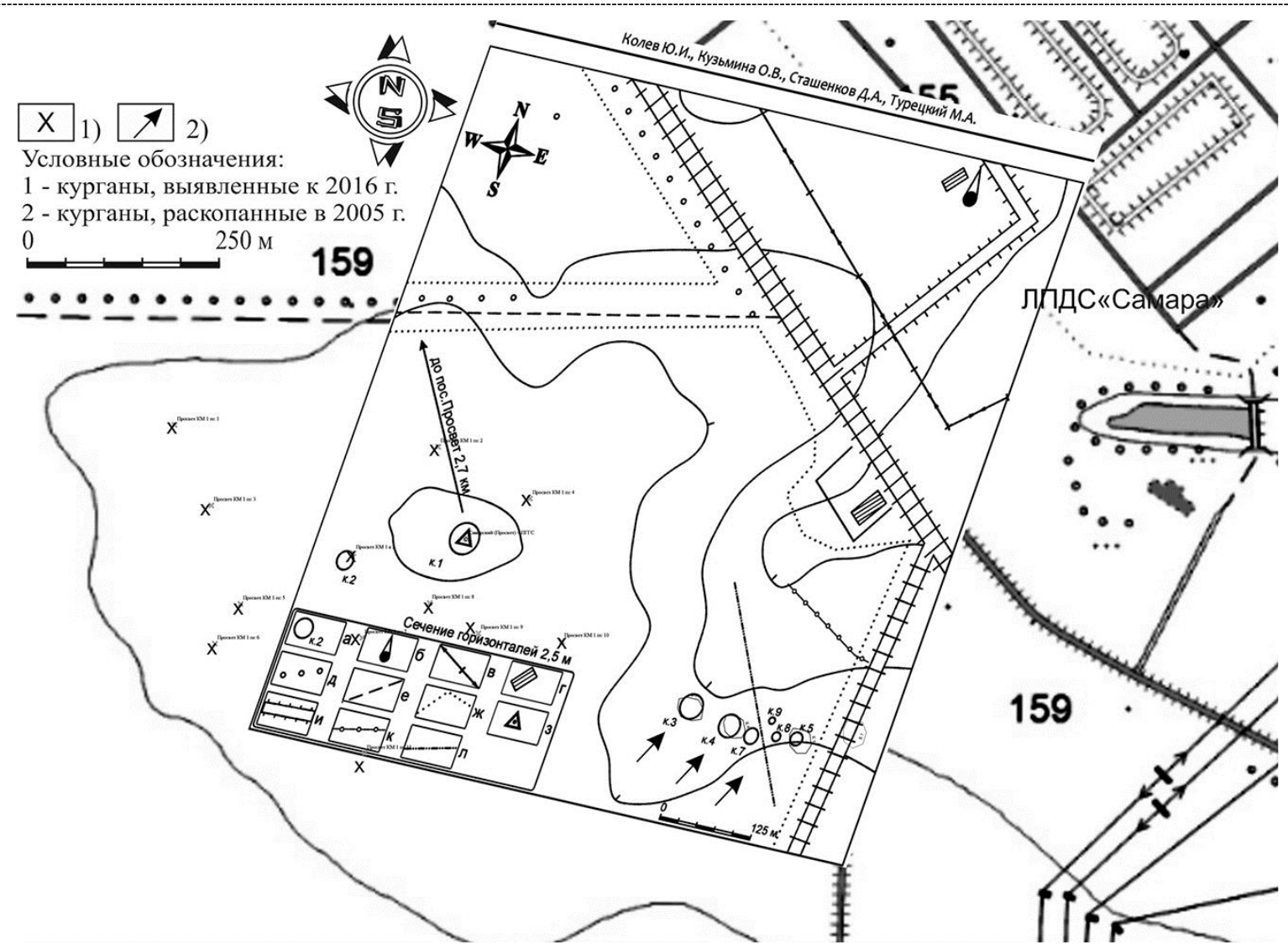

Рисунок 4 - Архивный план курганного могильника - «Самарский (Просвет) I» (2005 г.). Крест наклонный отмечает курганы, выявленные И.И. Дрёмовым по данным ДЗ3 


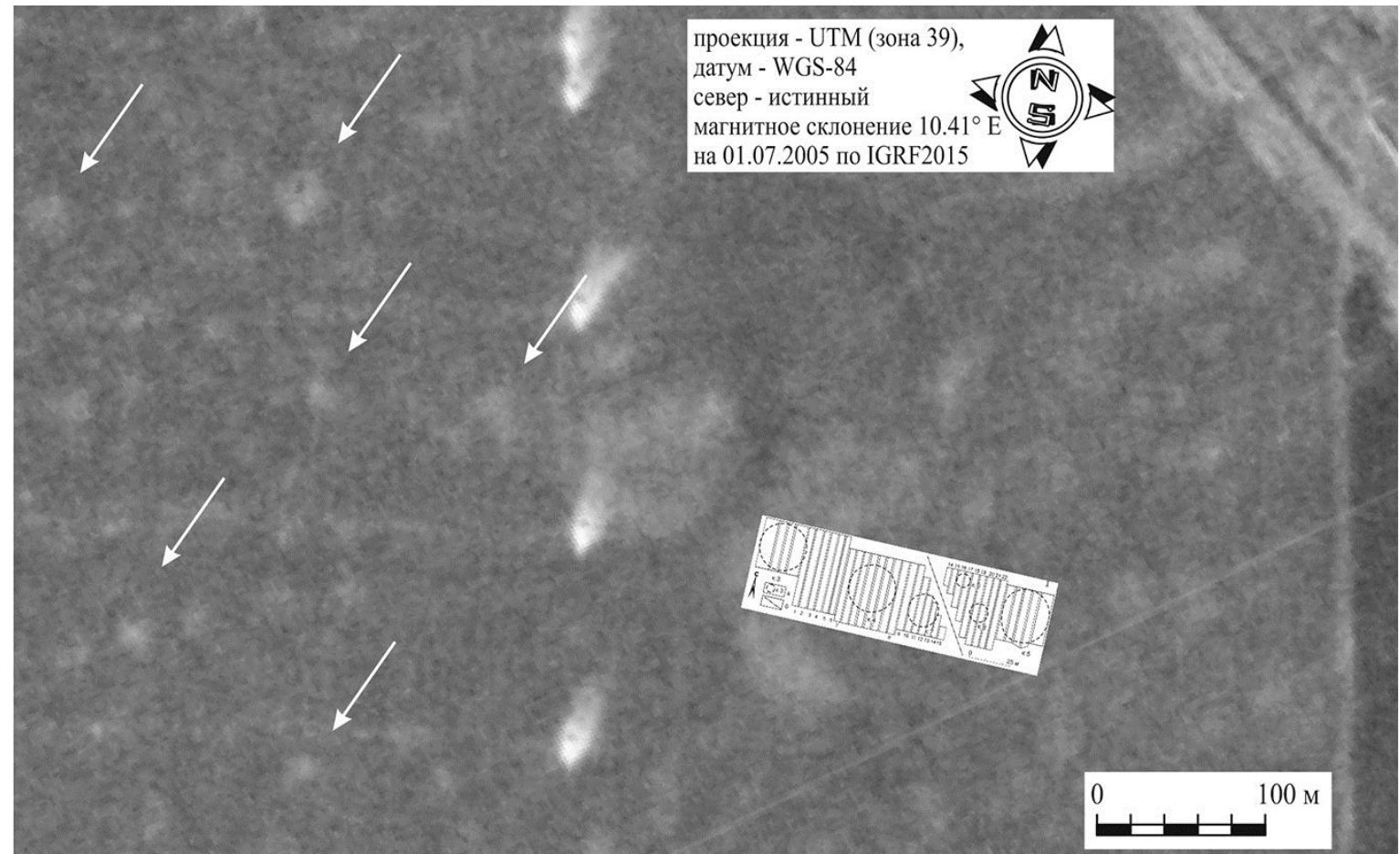

Рисунок 5 - Раскопанные в 2005 г. курганы №№ 3-5, 7-9 из состава курганного могильника «Самарский (Просвет) I». План раскопа спроецирован на космический снимок. Дата съемки 01.09.1971 г. Стрелками отмечены зоны пикселизации, верифицированные И.И. Дрёмовым как курганы

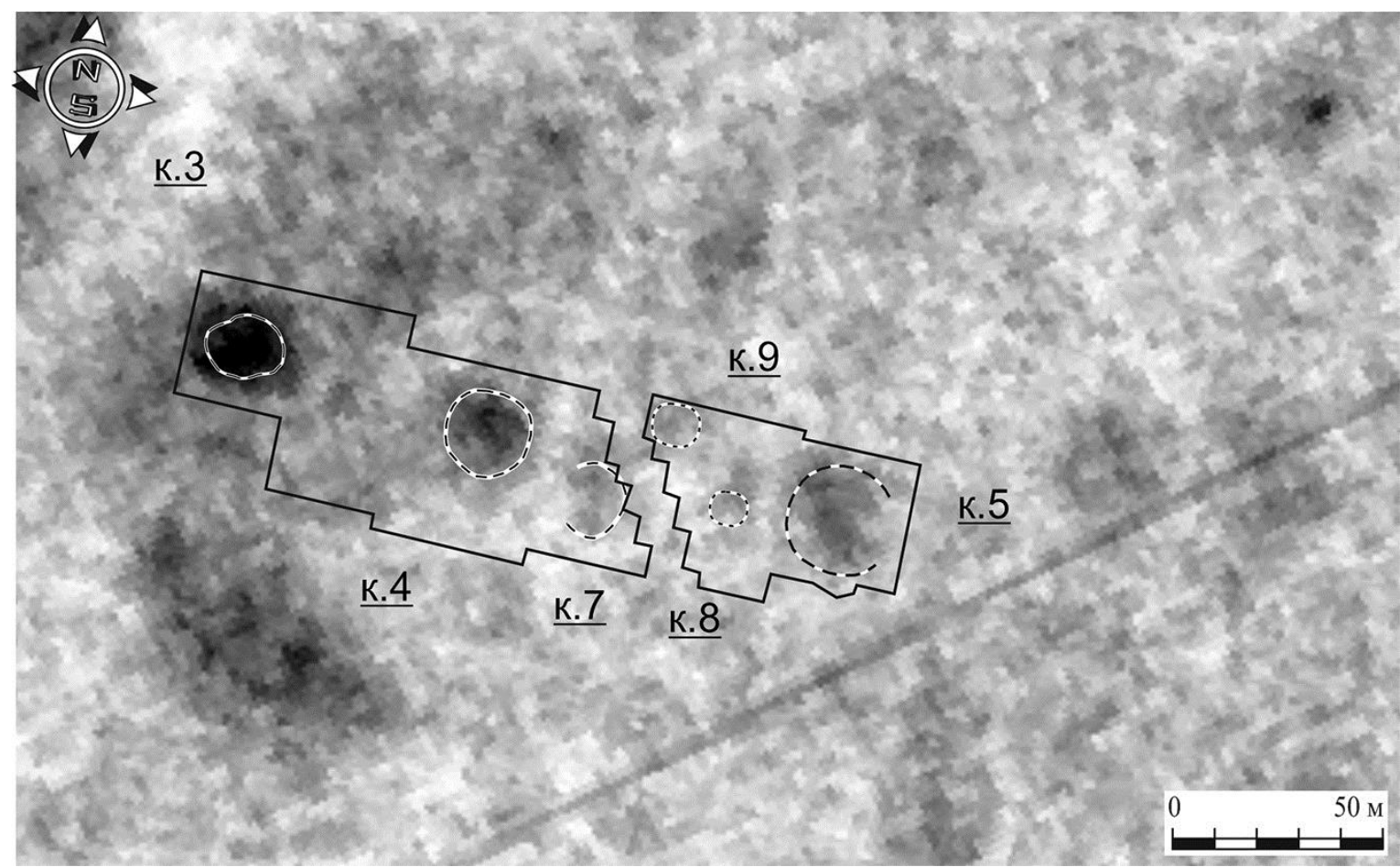

Рисунок 6 - Курганный могильник «Самарский (Просвет) I».

Полигоны чёрного цвета очерчивают раскоп 2005 г.

Штрих-линии отмечают внешний контур погребенной почвы под насыпями курганов

Затем на этот же план были нанесены все курганы, выявленные всеми вышеупомянутыми исследователями. Местоположения всех курганов, кроме выявленных И.И. Дрёмовым почвенных структур № 5 и № 9, совпали с зонами контрастной пикселизации, выделенные минимум на двух-трех космоснимках из различных условных блоков. Курганы №№ 6-7 и №№ 9-11 с планов 1973 и 1975 годов могут быть соотнесены с различными зонами контрастной пикселизации, что обусловлено невысокой точ- ностью самих этих планов и, соответственно, дрейфом их привязки.

При итоговом сведении оказалось, что на всех проанализированных данных ДЗ3 зоны контрастной пикселизации совпадают в 31 месте. В 9 из этих мест оказались расположены ранее выявленные и закоординированные С.А. Кондратьевым и И.И. Дрёмовым курганы. На месте раскопанных в 2005 г. курганов на некоторых современных снимках виден контур старого раскопа. 
Опираясь на опыт вышеупомянутых исследователей в поле, можно предположить, что 31 место совпадения всех зон контрастной пикселизации соответствует на местности курганам, большинство из которых полностью распахано. По этой, самой консервативной оценке, реконструируется курганный могильник, включающий в себя не менее 31 кургана, не считая раскопанных и уничтоженных. Большинство его насыпей (29), реальных и гипотетических, тяготеет к ЮВ краю курганного поля, в своё время выделенного А.Ф. Кочкиной в отдельный памятник.

Если предлагаемая модель анализа данных ДЗ3 верна, то курганный могильник «Самарский (Просвет) I» оказывается одним из самых крупных в регионе. По подсчётам автора, из 830 проанализированных курганных могильников Самарской области [11] в составе только 20-25 из этих памятников было зафиксировано от 20 до 40 курганных насыпей, а в составе 60 памятников - от 10 до 19 курганов. Все остальные курганные могильники включали в себя до 10 зафиксированных насыпей. Впрочем, есть веские основания считать эти оценки чрезвычайно заниженными. Для территории курганного могильника «Самарский (Проcвет) $I »$, количество зон контрастной пикселизации на каждом из космоснимков и на любой их комбинации существенно превышает число выявленных всеми исследователями курганов в поле (см. выше).

При этом мы основываемся на консервативной оценке численности курганов, которая учитывает совпадений зон контрастной пикселизации, выявленных на всех космоснимках. Однако количество таких зон начинает возрастать, если проводить сравнения блоков данных ДЗЗ. Например, при попарном сравнении блоков обнаружилось 40 мест, где совпали зоны контрастной пикселизации, выделенные на современных панхроматических и мультиспектральных снимках; из этого сравнения исключены архивные панхроматические снимки. Так же в 32 местах совпали зоны контрастной пикселизации, выделенные на архивных и современных панхроматических снимках; из этого сравнения исключены современные мультиспектральные снимки. Не менее чем в 49 местах совпали зоны контрастной пикселизации, выделенные на архивных панхроматических и современных мультиспектральных снимках; из этого сравнения исключены современные панхроматические снимки.

Более того, согласно верхней оценке, основанной на анализе только архивных панхроматических снимков, перед нами предстаёт поражающее воображение курганное поле, включающее не меньше 180 объектов! Такое допущение полностью игнорировать невозможно: все выявленные исследователями курганы, в том числе раскопанные в 2005 г, уверенно соотносятся именно с этими данными ДЗ3.

Косвенным признаком возможности такого явления служит пространственное положение участка местности, на котором разместились все вышеуказанные объекты. В плане геоморфологии этот участок представляет плоское плато в форме овала, протянувшееся по оси СЗ-ЮВ приблизительно на 44,3 км, явно выраженное в рельефе и переданное горизонталями на топопланах. Высотная отметка 163 м в Балтийской системе высот (отметка знака ПГГС, установленного на кургане № 1 из состава курганного могильника «Самарский (Просвет) I»), подтверждает, что это плато является доминирующим в радиусе минимум 34 км. Фактически все выявленные курганы и зоны контрастной пикселизации образуют несколько линий и групп - в границах этого плато.
В итоге сформировался набор вероятностных моделей количества и местоположения возможных археологических объектов в границах участка местности, очерченного на рисунке 7. Некоторые из этих моделей примиряют точки зрения всех предыдущих исследователей, но практически все указывают на возможную угрозу сохранности данного памятника археологии. Проецирование на описанную местность самого актуального на момент написания статьи космического снимка (выполнен 28.01.2018 г., предоставлен геосервером Google Earth) однозначно указывает на прохождение очередного коридора коммуникаций через несколько зон контрастной пикселизации и три кургана (п/с № 1, п/с № 8, п/с № 9), выявленных И.И. Дрёмовым (рис. 8).

В более привычных терминах - в 2017 году какая-то траншея и площадной объект оказались на местах расположения весьма вероятных курганов. Автор не располагает сведениями об охранных работах, проведённых на этой территории, которые могли бы подтвердить либо опровергнуть вышеизложенное.

Возможно, опасения автора могут показаться чрезмерными, а иллюстрируемые изображения - не очень убедительными. В таком случае стоит обратить внимание на ряд следующих примеров.

Всего за период 2015-2018 гг. в Самарской области были анонсированы раскопки не менее 28 курганов, из которых 24 - в зонах строительных работ. Для территорий многих из этих памятников автор располагает наборами разнородных данных ДЗ3. Некоторые из этих наборов включают изображения, превосходящие по качеству снимки, использованные при анализе курганного могильника «Самарский (Просвет) I», что придаёт убедительность всей аргументации.

Например, при проведении анализа данных Д33 по вышеуказанной методике было зафиксировано не менее 53 зон характерной контрастной пикселизации к востоку от комплекса смешения и перекачки нефти НПС «Дружба» (Волжский район, Самарская область, рис. 1: 2). Кроме них, на серии мультиспектральных космических снимков, предоставленных геосервером Google Earth, была запечатлена прокладка траншеи нефтепровода и процесс упреждающих охранно-спасательных археологических раскопок пяти курганов, оказавшихся на её пути (рис. 9).

В данном случае мы наблюдаем охранно-спасательные раскопки курганов №№ 1, 3, 5, 7, 8 из состава курганного могильника «Николаевка II», проведённые под руководством М.С. Седовой (Седова, 2016, устный доклад на «ХІІ Самарская археологическая конференция»). Все вышеупомянутые зоны контрастной пикселизации совпадают как с курганами по М.С. Седовой, так и с раскопанными ранее, поскольку этот памятник неоднократно исследовался. Качество панхроматического снимка не оставляет сомнений в интерпретации остальных зон пикселизации - именно как курганов.

Проецирование контура траншеи нефтепровода на этот снимок указывает на её опасное сближение с несколькими, ещё не открытыми курганами, некоторые из которых оказались припорошены отвалом (рис. 10).

Любопытно, но после публикации этой информации [12, с. 232] строящийся трубопровод в 2016 году внезапно был пущен в обход всего этого курганного поля. В итоге просто по счастливой случайности ни один курган, выявленный по данным Д33, не пострадал в ходе строительных работ. 
Вальков Д.В.

Курганы Самарской области в фокусе спутниковых снимков

Исторические науки и археология

Однако есть и печальные примеры.

В 2015 г. под руководством В.А. Цибина были проведены охранно-спасательные археологические раскопки в границах курганного могильника «Muхайловский II» (Кинельский район, Самарская область, рис. 1: 3). Были раскопаны курганы №№ 2, 3 и 7 (Цибин, 2016, устный доклад на «XII Самарская археологическая конференция»). На эту территорию автором было проведено совмещение современных космических снимков, на которых запечатлён процесс охранно-спасательных археологических раскопок этих курганов, с архивными снимками. Качество этих космоснимков также не требует постобработки для интерпретации характерных зон контрастной пикселизации. Это явные курганы, практически все опоясанные характерными «ровиками» - горизонтами снятия почвы. Установлена положительная корреляция местоположения этих зон с выявленными в поле курганами с точностью до первых метров. Кроме того, на территории курганного могильника выделено порядка 5-7 таких зон, помимо зафиксированных исследователями в 2015 г. (рис. 11). При совмещении местоположения этих зон с контурами раскопов, видимых на космических снимках 2015 г., выяснилось, что крупный курган диаметром около 30 м, находящийся между раскопанными курганами № 2 и № 3, ускользнул от внимания исследователей. За рамками настоящей статьи остаются обстоятельства первоначального открытия и обследования данного памятника археологии.
Важнее отметить, что в ходе хозяйственного освоения окружающей территории, на южной половине этого кургана, оказалась возведена земляная обваловка (рис. 12). Кроме того, ещё нескольким не выявленным насыпям угрожает явная опасность при дальнейшем расширении зоны строительных работ в этом краю экстенсивной нефтедобычи.

На этом фоне оптимистично смотрятся охранноспасательные раскопки, проведённые на курганном могильнике «Конезавод II» (Красноярский район, Самарская область, рис. 1: 4). В 2017 г. Н.В. Костин раскопал курган № 27, ранее выявленный экспедицией ООО НПЦ «У.Т.Р.» [13, с. 80]. Автор принимал непосредственное участие и в анализе данных ДЗ3 на территорию данного могильника и в верификации их в поле в 2015 году. Указанный курган был детектирован на двух различных космических снимках независимо, но, по причине аморфной формы и скептического отношения автора к возможностям анализа данных Д33, в число курганов не зачислен. При проведении верификации в поле, прикрытом первой порошей и стеблями подсолнечника, этот объект был оставлен «в сильном подозрении» и получил статус «почвенной структуры № 27 (возможно, сильно распаханный курган)». Необходимо отдать должное последующим исследователям, которые полноценным раскопом положили конец колебаниям автора в данном вопросе [14]. Данный пример показывает, насколько важна постоянно нарабатываемая обратная связь между оператором анализа данных ДЗ3 и археологами в поле.

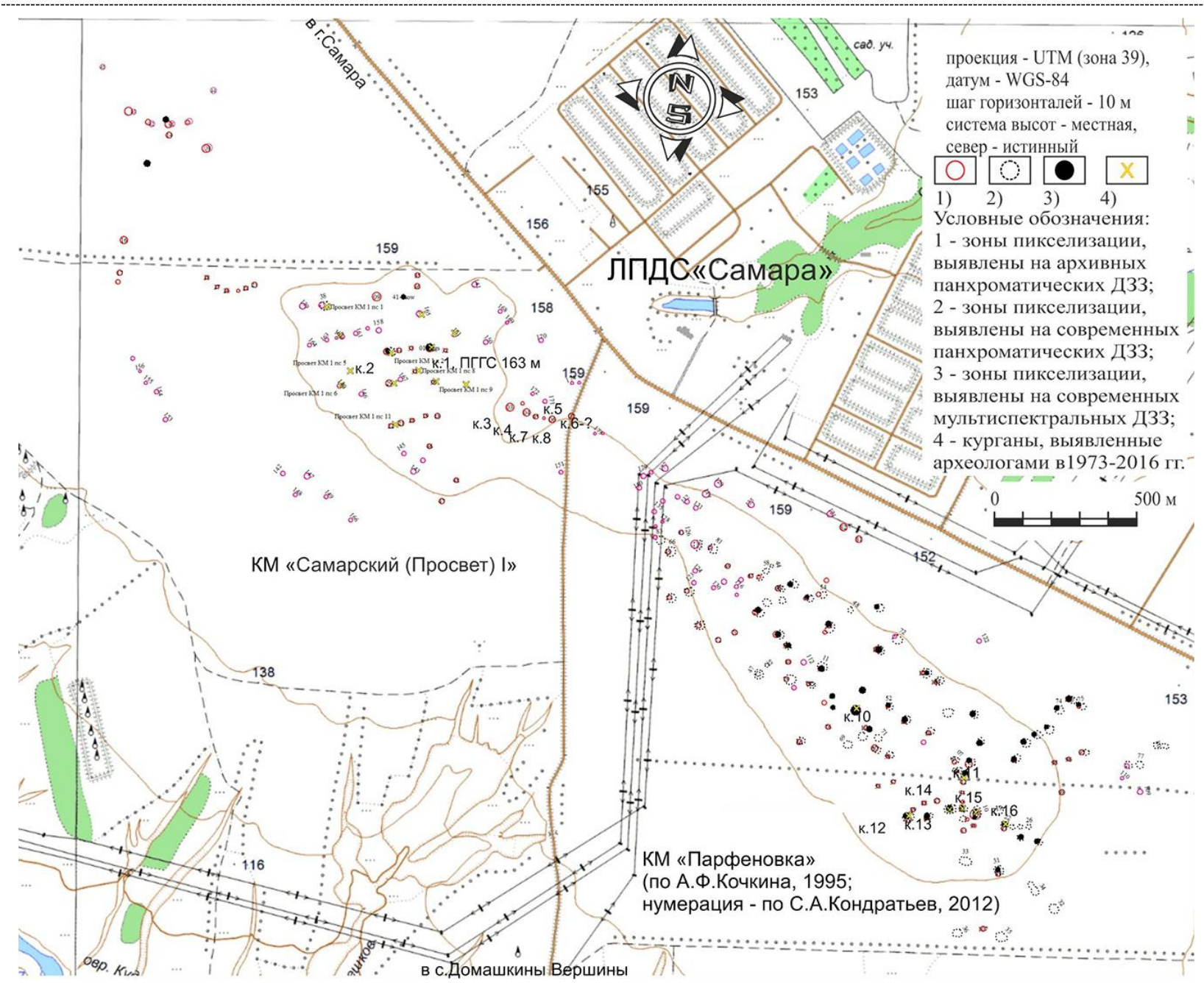

Рисунок 7 - Зоны пикселизации, выявленные на разнородных ДЗ3.

Территория и ближайшая округа курганного могильника «Самарский (Просвет) I». Волжский и Кинельский районы, Самарская область 


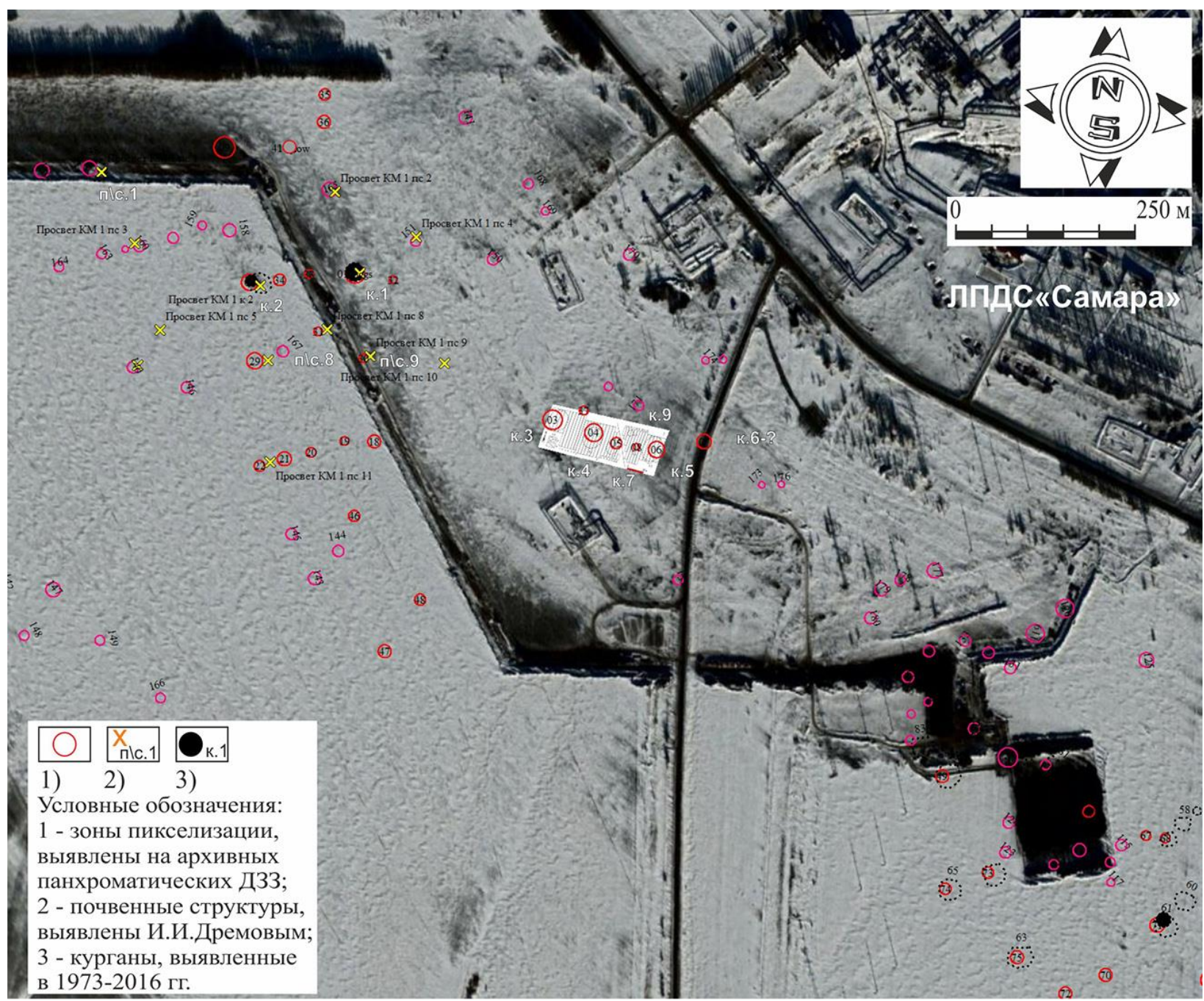

Рисунок 8 - Строительные работы, проводимые в границах территории ОАН курганного могильника «Самарский (Просвет) І».

Дата космоснимка - 28.01.2018 г. ЛПДС «Самара», Волжский и Кинельский районы, Самарская область

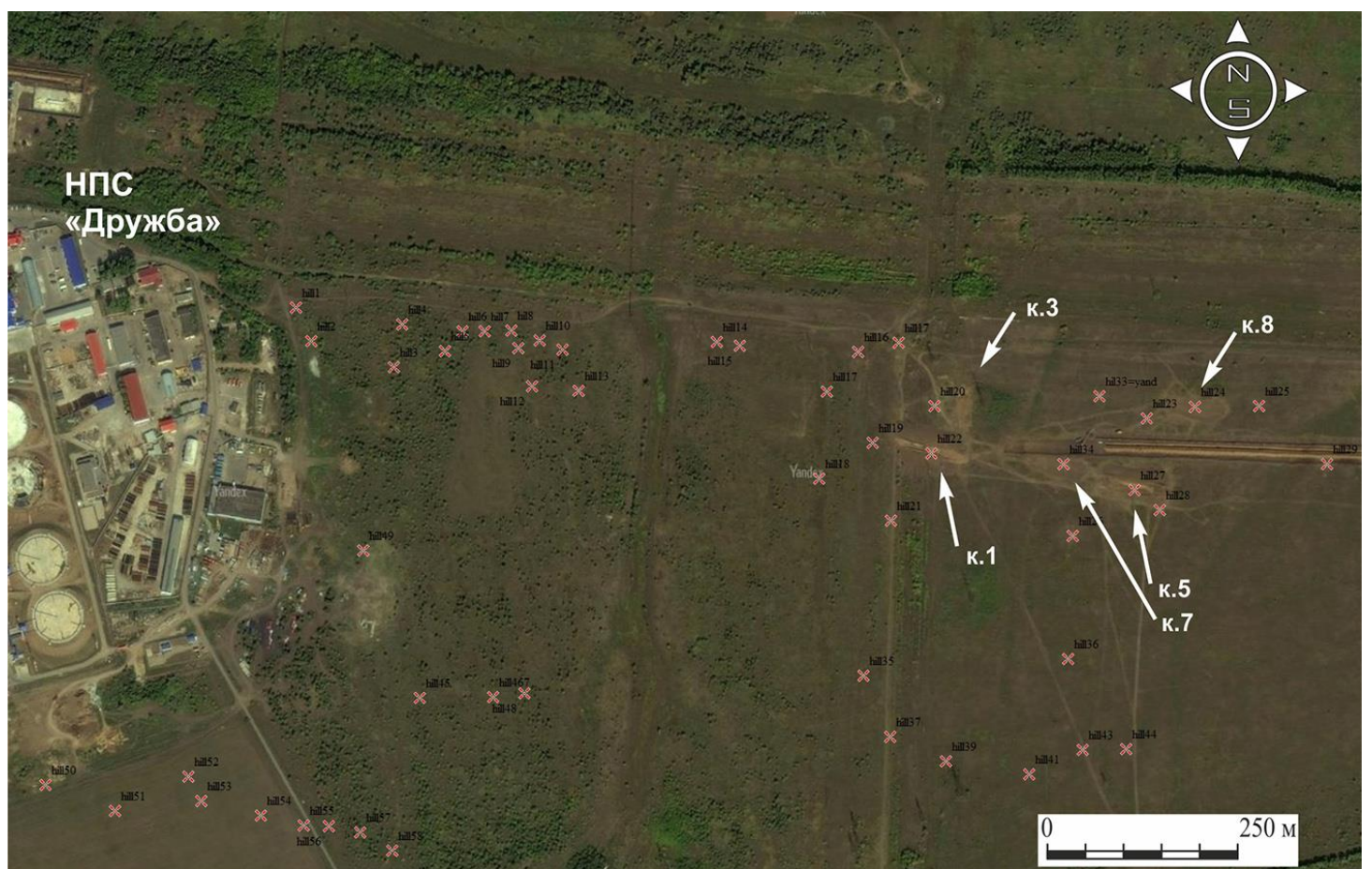

Рисунок 9 - Территория курганного могильника «Николаевка II», Волжский район, Самарская область. Траншея нефтепровода и раскопы курганов (указаны стрелками) видны на современном космоснимке. Белые наклонные кресты отмечают курганы, выявленные по архивному космоснимку 


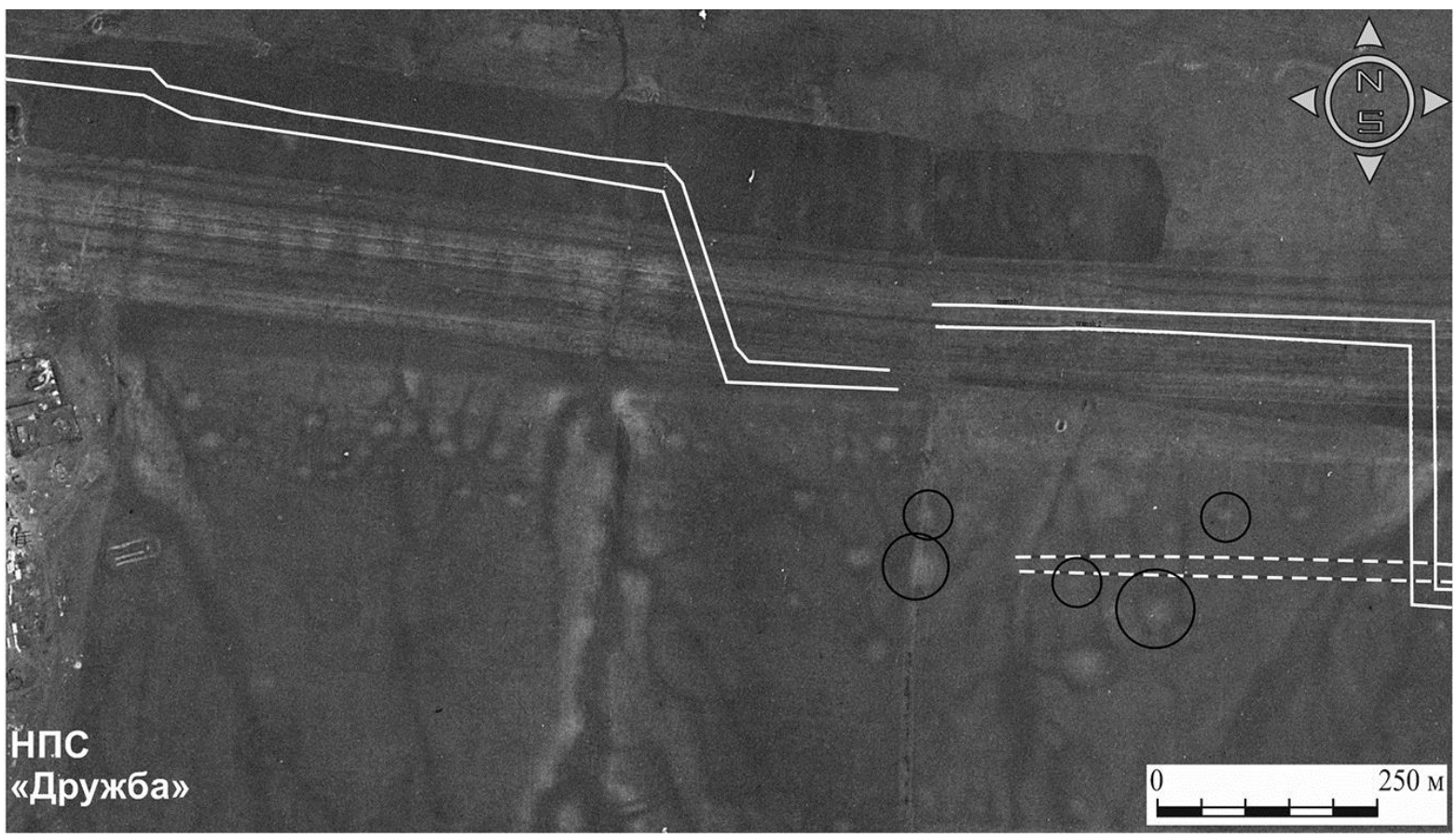

Рисунок 10 - Территории курганного могильника «Николаевка II», Волжский район, Самарская область. Дата снимка 1968 г. Зона строительных работ летом 2015 г. отмечена белым пунктиром. Белая сплошная линия отмечает прокладку траншеи в обход. Раскопанные в 2015 г. курганы заключены в окружности

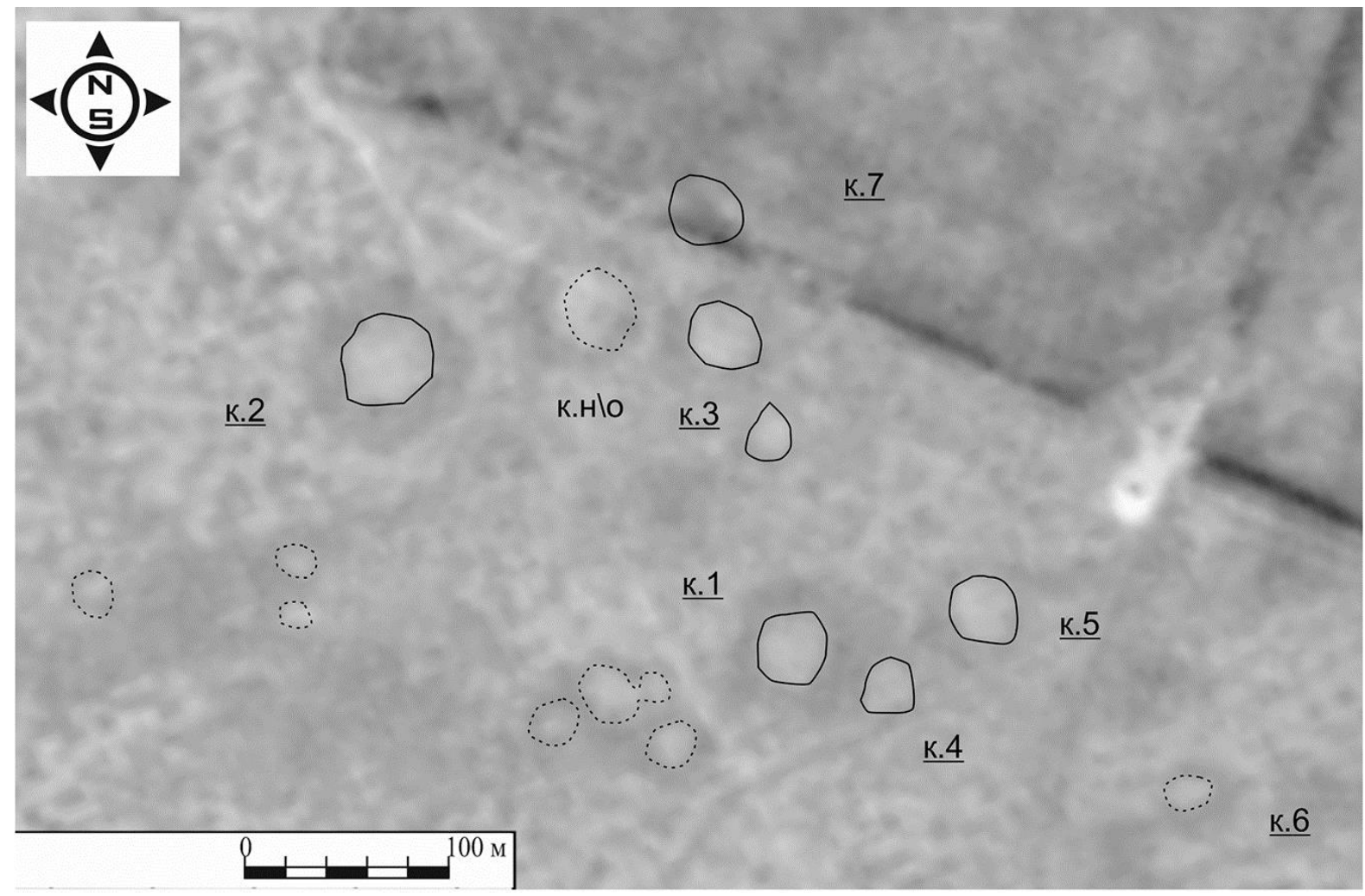

Рисунок 11 - Курганный могильник «Михайловский II», Кинельский район, Самарская область. Дата снимка: 1968 г. Пунктиром очерчены вероятные курганы, «к.н/о» - курган не обнаруженный

Следующий пример - проведение охранно-спасательных раскопок на курганном могильнике «Садгород $I V \gg$ в 2016 г. (Кинель-Черкасский район, Самарская область, рис. 1: 5). На территорию этого памятника информативные космические снимки в распоряжении автора отсутствуют. По этой причине невозможно увидеть, какой, полностью распаханный, курган спасла от разрушения только скрупулёзность исследователей, накрывших сплошным раскопом обширное межкурганное пространство [15, с. 195].
Оценить качество охранно-спасательные раскопок, проведённых на территории курганного могильника «Безенчук VI», автор не может, поскольку не располагает данными о точном местоположении раскопанного в 2017 г. кургана № 1 из его состава [16, c. 17]. Зато имеется возможность оценить состояние дел на близко расположенных курганных могильниках «Безенчук I», «Безенчук II», «Безенчук III» и «Безенчук $I V \gg$ (Безенчукский район, Самарская область, илл. 1, № 6). По итогам проведённой в том же году 
инвентаризации, в составе вышеперечисленных объектов археологического наследия было поставлено на государственный учет 37 курганов - согласно Приказу № 5 от 16.01.2018 г. [15]. Со своей стороны, на окружающую территорию автор располагает обширным набором данных Д33, начиная от аэрофотоснимков с борта самолетов-разведчиков Люфтваффе 1942 года и до фотоснимков с борта Международной космической станции 2016 и 2018 годов (миссии MKC (ISS)-47, МКC (ISS)-48 и МКС (ISS)-55/56), специально выполненных для наших задач. Участок местности, в границах которого некогда были возведены многочисленные (в том числе и закоординированные в 2017 г.) курганы, представляет собой интересное геоморфологическое образование. Это трапециевидной формы выступ третьей левобережной террасы р. Волга, размерами приблизительно 2,5 × 1,5 км, образованный долиной р. Безенчук и причудливыми изгибами старых оврагов (русел ?), впадающих в неё. Площадка террасы возвышается над окружающей местностью на 5-7 метров как своеобразное плато. Буквально напротив, на левобережной террасе р. Безенчук, находится курганный могильник «Сосновка I» / «II», включающий не менее 82 курганов, - объект многолетних экспериментов автора по верификации различных данных ДЗ3. На его примере можно обоснованно утверждать, что весь сложный характер данного микрорайона заслуживает намного более тщательного и скрупулёзного, истинно археологического обследования, в ходе которого анализ данных Д3З должен многократно чередоваться с верификацией в поле. При игнорировании такой поисковой стратегии точное количество археологических объектов в границах вышеупомянутого «плато» остаётся неизвестным, но, как минимум, в несколько раз больше заявленного в Приказе № 5. В числе пропущенных при инвентаризации 2017 г. имеются курганы: диаметром до 26-28 м, опоясанные ровиками, от- меченные высотными отметками на современных топографических картах, указанные на инструментальных планах предшествующих исследователей и т.д.

Приведённые примеры делают ситуацию непредсказуемой в отношении многих других памятников, исследованных за последнее время даже на высоком методическом уровне. С другой стороны, эти примеры фокусируют внимание на двух серьёзных проблемах, заявленных в начале статьи.

Первая - это учет объектов археологического наследия. Очевидно, что за столетний период планомерного исследования региона были выявлены не только тысячи памятников археологии, но и накопилась сотни ошибок и разночтений в их наименовании, местоположении, описании и т.д. Ежегодная программа инвентаризации объектов археологического наследия это хороший проект, но эффективность его реализации силами одной организации не всегда очевидна, что иллюстрируется на примере обследования курганных могильников «Безенчук I»- «Безенчук $I V »$.

По мнению автора, для решения первой задачи необходим консолидированный подход всего заинтересованного пула самарских археологов. В этом подходе роль и приоритет государственного органа должны состоять в институализировании областной ГИС учета объектов культурного наследия региона, построенной на основе консенсуса интересов специалистов, и организации взаимовыгодного информационного обмена - для её наполнения и корректировки. Автор убеждён, что десятки археологических экспедиций и специалистов, ежегодно работающих в Самарской области, смогут за ближайшие пять лет навести порядок в таком «Перечне» - при разумном и прозрачном администрировании. Также несомненно, что заинтересовать специалистов и наладить работу такой, фактически самоорганизующейся, системы гораздо сложнее, чем просто делать по несколько десятков обследований памятников в год.

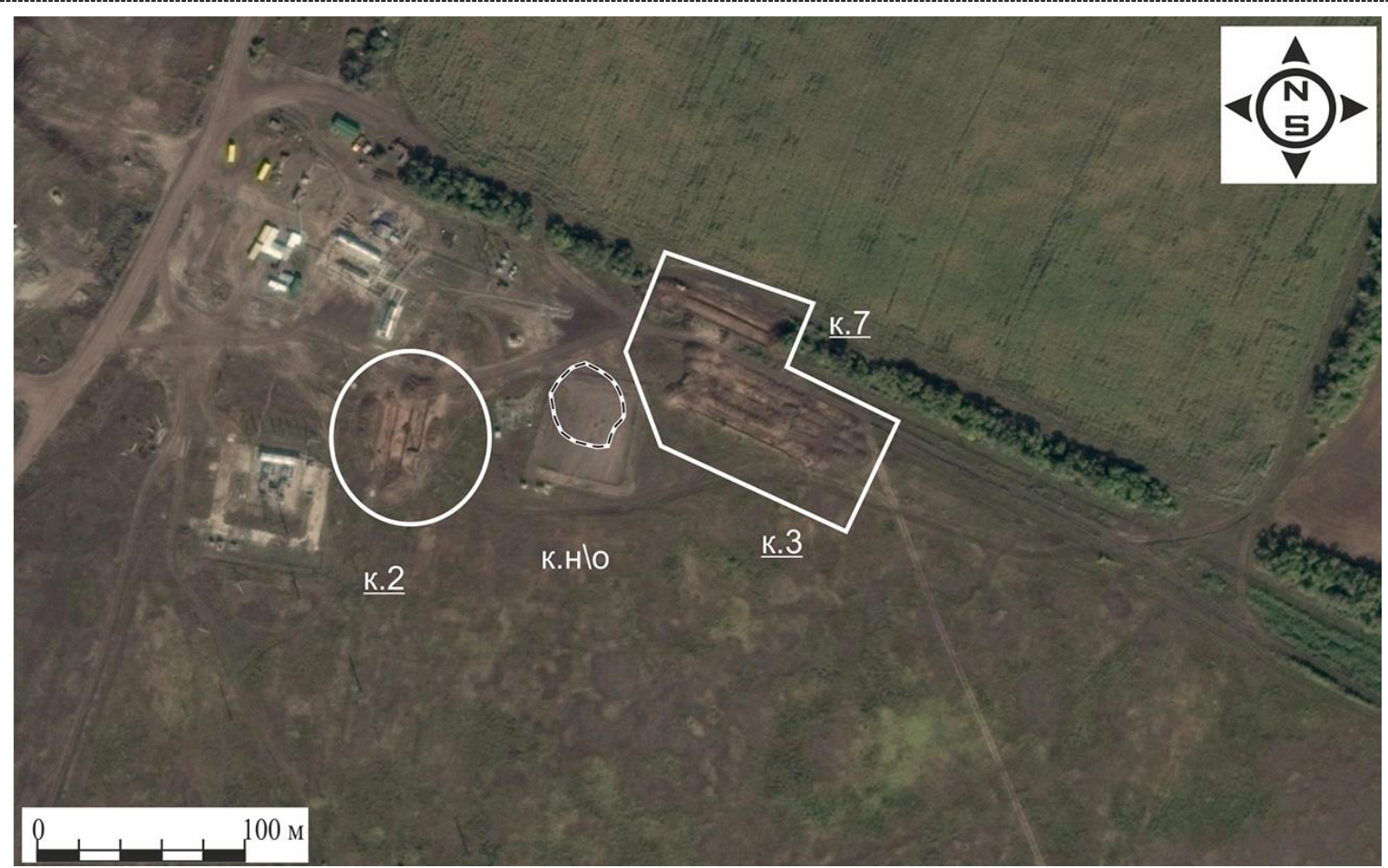

Рисунок 12 - Курганный могильник «Михайловский II», Кинельский район, Самарская область. Дата снимка 28.08.2015 г., с борта KA World View 2.

Контур белого цвета отмечает раскопанные в 2015 г. курганы.

Штрих-линия отмечает местоположение не обнаруженного кургана, частично перекрытого обваловкой 
Вторая проблема - это поиск памятников археологии, не обнаруживаемых традиционными полевыми методами, она является принципиально важной для обследования зон хозяйственного освоения. Сокрушительный эффект пренебрежения данными Д3З при организации проведения даже новейших охранно-спасательных археологических раскопок наглядно проиллюстрирован выше. Число таких примеров можно легко умножить пропорционально активности археологической организации, ведущей охранноспасательные раскопки. По всей видимости, наиболее надёжная исследовательская стратегия, исключающая как утомительную возню с малопонятными космическими снимками (и прочими неразрушающими методами), так и дающая однозначный эффект, - это исследование сплошным раскопом всего землеотвода, если в зону строительства попадает хотя бы часть территории погребального памятника. При всей свой финансовой и временной затратности, такая методика себя оправдала при исследовании курганных могильников «Просвет I» и «Садгород $I V »$. Однако эти триумфальные результаты были достигнуты раскопами площадью «всего лишь» до

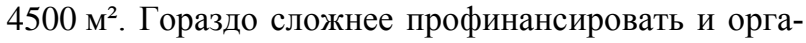
низовать такую же работу на площадях порядка 25000-30000 м², что примерно соответствует размаху строительных работ в границах вышеописанного курганного поля «Самарский (Просвет) I», запечатлённых на снимке от 28.01.2018 г.

Для оптимизации таких затрат опять же пригодится комплексный анализ данных Д33, который поможет увереннее обосновать соответствующие сметные расчеты, пролоббировать охранное перепроектирование либо сконцентрировать усилия археологов в поле - на более перспективных участках.

\section{Список литературы:}

1. Кузьминых С.В., Сафонов И.Е., Сташенков Д.А. Вера Владимировна Гольмстен: Материалы к биографии. Самара: ООО «Офорт», 2007. 168 с.

2. Гольмстен В.В. Дневник Восточной экспедиции. 1921 г. // Архив ИИМК РАН. Ф. 44. Д. 3.

3. Гошко Т.Ю., Агапов С.А., Отрощенко В.В. Металеві казани з Великого Степу за доби пізньої бронзи. Київ: ІА НАН України, 2018. 328 с.

4. Вальков Д.В., Большакова Н.В., Кошутин Р.А. Опыт верификации памятников археологии, открытых экспедициями Общества археологии, истории и зтнографии методами анализа геопространственных данных. На примере «курганника у с. Домашка» (в печати).

5. Камаев В.В. Отчет об археологических разведках по р. Самаре в Куйбышевской области по открытому листу № 388. Куйбышев, 1976 // Архив ИА АН CССР. Р-1. № 5800.

6. Кочкина А.Ф. Отчет о раскопках I Красносюндюковского городища в Ульяновском районе Ульяновской области и разведках в Волжском районе Самарской области в 1991 году. Самара, 1991 // Архив ИА РАН. Р-1. № 16845.

7. Колев Ю.И., Кузьмина О.В., Сташенков Д.А., Турецкий М.А. Курганный могильник Просвет I в Волжском районе Самарской области // Бронзовый век. Эпоха героев (по материалам погребальных памятников Самарской области). Самара: АНО «Издательство СНЦ», 2012. С. 248-295.
8. Кондратьев С.А. Отчет о результатах проведения разведочных археологических исследований на территории муниципального района Кинельский Самарской области в 2012 году по Открытому листу № 1077. Самара, 2013 // Архив ИА РАН. Р-1. № 34717 .

9. Дрёмов И.И. Отчет об археологическом обследовании участков реконструкции магистрального нефтепровода в Клявлинском, Исаклинском, Сергиевском, Кинельском, Волжском районах Самарской области в 2016 г. Саратов, 2016 // Архив ИА РАН. Р1. № 51193.

10. Перечень выявленных объектов археологического наследия Самарской области [Электронный ресурс] // Управление государственной охраны объектов культурного наследия Самарской области. http://nasledie.samregion.ru.

11. Архив Историко-эко-культурной ассоциации «Поволжье».

12. Вальков Д.В. Интеграция данных ДЗ3 и анализ микрорельефа - опыт развития методики полевого археологического исследования // Самарский край в истории России: мат-лы межрегион. науч. конф., посв. 165-летию со дня основания Самарской губернии и 130-летию со дня основания СОИКМ им. П.В. Алабина. Вып. 6. Самара: АНО «Издательство СНЦ», 2017. С. 231-241.

13. Бойцов И.А. Отчет об итогах натурного полевого обследования земельного участка, отводимого под проектирование и строительство волоконнооптической линии связи на объекте - «Автодорожные телекоммуникационные сети в обочине автомобильной дороги общего пользования федерального значения М5 «Урал» в границах Сергиевского, Красноярского и Волжского районов и г.о. Самара, Самарской области в 2016 году. Самара - Москва, 2017 // Архив ИА РАН. Р-1.

14. Костин Н.В. Отчет о проведении раскопок кургана № 25 курганного могильника «Конезавод II» на территории муниципального района Красноярский Самарской области (по открытому листу № 2185 в 2017 году). Самара, 2018 // Архив ИА РАН. Р-1.

15. Васильева И.Н., Кулакова Л.С., Салугина Н.П., Рослякова Н.В. Раскопки курганного могильника позднего бронзового века Садгород IV // Самарский край в истории России: мат-лы межрегион. науч. конф., посв. 165-летию со дня основания Самарской губернии и 130-летию со дня основания СОИКМ им. П.В. Алабина. Вып. 6. Самара: АНО «Издательство СНЦ», 2017. С. 172-196.

16. Цибин В.А., Горбунов Н.А., Кормилицын Д.В., Мясников М.О., Шигаев В.Н., Прохорова К.Д. Охранно-спасательные археологические раскопки в Безенчукском районе // Археологические открытия в Самарской области 2017 года. Самара: АНО «Издательство СНЦ», 2018.

17. Об утверждении границ территорий выявленных объектов археологического наследия, включённых в перечень выявленных объектов культурного наследия Самарской области: приказ УГООКН Самарской области от 16.01.2018 г. № 2 [Электронный ресурс] // Управление государственной охраны объектов культурного наследия Самарской области. http://nasledie.samregion.ru/sites/nasledie.samregion.ru/ files/docs/2.pdf. 


\title{
BURIAL MOUNDS OF THE SAMARA REGION IN THE FOCUS OF SATELLITE IMAGES
}

(C) 2020

Valkov Denis Vladimirovich, head of Archeological Studies Department «Universal Research and Studies» Research and Development Centre (Samara, Russian Federation)

Abstract. The paper focuses on two archaeological problems - the correctness of the accounting system for archaeological monuments and the effectiveness of their detection, especially in the areas of upcoming construction work. The urgency of the problems is revealed by the author on the history of the study of the burial mound «Samarsky (Prosvet) I» as well as on the example of the survey site analysis of heterogeneous data in Earth remote sensing (ERS). It was concluded that the burial mound had been examined by at least 8 expeditions within the time period of 1973-2016. During this time, the accumulated errors in the description had led to the situation when this burial mound, having a single name, was recorded twice in two different administrative districts, having 2 difference reference numbers in the system of accounting for objects of the archaeological heritage of the Samara Region. The author created a set of ERS data for the area of the burial mound, which included archival and modern satellite images. Then all the data and the locations of the mounds identified by the previous researchers were brought to a single projection by means of a purpose designed software. From 31 to 180 areas of specific contrast pixilation are allocated according to various ERS data. The locations of all mounds previously identified in the field match them. Consequently, many of these areas may correspond to fully agriculturally plowed mounds, the safety of which is endangered by the close oil pipelines construction sites. This method was used to check the territory of four more burial mounds surveyed within 2015-2017 time period and located on the construction sites. Mounds that hadn't been identified by researchers earlier and consequently damaged during the construction work were found. The author comes to the conclusion that the field archaeological survey should be preceded by the analysis of heterogeneous remote sensing data (ERS); the most reliable method is the study of the burial mounds by means of excavation of a «wall-to-wall» area covering the inter-mound space. However, this method, being the most expensive, requires adjustments based on the ERS data and other non-invasive methods.

Keywords: Samara Region; burial mound «Samarsky (Prosvet) I»; burial mound «Nikolaevka I»; burial mound «Mikhailovsky II»; burial mound «Konezavod II»; analysis of the Earth Remote Sensing Data (ERS Data); GIS; satellite images; accounting of objects of archaeological heritage; destruction of archaeological monuments/landmarks.

\section{ВЫМЕРШЕЕ ПЛЕМЯ КАЛУСА КАК ГЕГЕМОН ЮЖНОЙ ФЛОРИДЫ В XVI-XVII ВЕКАХ: ПРИЧИНЫ ЕГО ВОЕННОГО ЛИДЕРСТВА СРЕДИ ДРУГИХ НАРОДОВ ФЛОРИДЫ}

(C) 2020

\author{
Ашрафьян Константин Эдуардович, аспирант \\ кафедры археологии, древней истории и истории средних веков \\ Московский государственный областной университет (г. Москва, Российская Федерация)
}

Аннотация. Результатом работы явилось выявление и обозначение нескольких краеугольных моментов в глубокой тысячелетней истории общества аборигенов Южной Флориды - индейцев калуса (калуза), которые привели этот народ в положение лидера в регионе. В результате исследования были объединены и использованы множественные старые письменные источники, упоминающие различные моменты соприкосновения испанцев с этой исчезнувшей цивилизаций, а также использованы новые документы - книги и диссертации ведущих профессоров Флориды и США, занимающихся проблемами исчезнувших народов региона Флориды. Помимо этого были изучены артефакты и реконструкции жизни аборигенов Южной Фориды при многочисленных посещениях музеев Флориды самим автором статьи. Была выдвинута гипотеза о важной зависимости между созданием больших многонаселенных жилищ у народа калуса, их образом жизни как рыболовов-охотников-собирателей и мобильной организацией военных сил, мобильностью всего общества в условиях ежегодных стихийных катаклизмов Флориды. Результатом работы явилось также удаление «белого пятна» в советской и российской научной литературе о достаточно древнем и нетипичном оседлом народе рыболовов-охотников-собирателей при освещении событий эпохи Великих открытий и столкновения двух миров во время испанской конкисты.

Ключевые слова: калуса; калуза; колонизация; конкистадоры; христианизация; атлатль; Маунт Ки; аборигены; Центральная Флорида; Флорида; индейцы; Северная Америка; США; калусахатчи; Ки Марко; Эрнандо де Фонтанеда; испанская корона; Понсе де Леон; Карлос; залив Эстеро; Антильские острова; индейцы; побережье Флориды; Тампа; эстуарий; общество рыболовов-охотников-собирателей. 